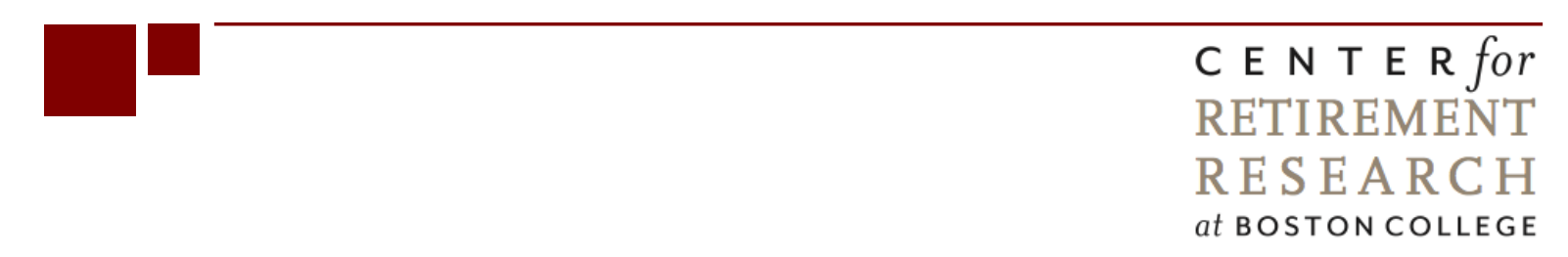

\title{
SOCIAL SECURITY ON AUTO-PILOT: INTERNATIONAL EXPERIENCE WITH AUTOMATIC STABILIZER MECHANISMS
}

Barry Bosworth and R. Kent Weaver

CRR WP 2011-18

Date Released: November 2011

Date Submitted: October 2011

Center for Retirement Research at Boston College

Hovey House

140 Commonwealth Avenue

Chestnut Hill, MA 02467

Tel: 617-552-1762 Fax: 617-552-0191

http://crr.bc.edu

Barry Bosworth is a senior fellow in economic studies at the Brookings Institution. R. Kent Weaver is a professor of public policy and government at Georgetown University and a senior fellow in governance studies at the Brookings Institution. The research reported here was performed pursuant to a grant from the U.S. Social Security Administration (SSA) funded as part of the Retirement Research Consortium (RRC). The opinions and conclusion expressed are solely those of the authors and do not represent the opinions or policy of SSA, any agency of the federal government, the RRC, the Brookings Institution, Georgetown University, or Boston College.

(C) 2011, Barry Bosworth and R. Kent Weaver. All rights reserved. Short sections of text, not to exceed two paragraphs, may be quoted without explicit permission provided that full credit, including (C) notice, is given to the source. 


\title{
About the Center for Retirement Research
}

The Center for Retirement Research at Boston College, part of a consortium that includes parallel centers at the University of Michigan and the National Bureau of Economic Research, was established in 1998 through a grant from the Social Security Administration. The Center's mission is to produce first-class research and forge a strong link between the academic community and decision-makers in the public and private sectors around an issue of critical importance to the nation's future. To achieve this mission, the Center sponsors a wide variety of research projects, transmits new findings to a broad audience, trains new scholars, and broadens access to valuable data sources.

\author{
Center for Retirement Research at Boston College \\ Hovey House \\ 140 Commonwealth Avenue \\ Chestnut Hill, MA 02467 \\ phone: 617-552-1762 fax: 617-552-0191 \\ e-mail: crr@bc.edu \\ crr.bc.edu
}

\section{Affiliated Institutions:}

The Brookings Institution

Massachusetts Institute of Technology

Syracuse University

Urban Institute 


\begin{abstract}
As the baby boom generation enters retirement, a long-forecast funding crisis of the Social Security system is about to become a reality. Many other high-income countries are faced with similar financial problems with their public pension systems. Some of those countries have adopted legislative measures to reduce their funding deficits, and a few have included automatic adjustment mechanisms by which staged adjustments would be made in either benefits or revenues without the need for new legislation. We examine the cases of automatic stabilizer mechanisms (ASMs) in Canada, Sweden, Germany and Italy, with the former two being relatively successful examples, while the latter two are cases of ASMs that were more problematic. Drawing on these international examples, we examine various automatic mechanisms that could be implemented in the United States. We consider three reforms: increase in the retirement age, adoption of a chained Consumer Price Index, and adjustment of the indexation of the taxable wage ceiling so as to stabilize the ratio of taxable to covered wages at its 1983 value of 90 percent. Together, these three reforms would reduce the 75-year actuarial deficit to about $1 / 2$ percent of taxable wages. We conclude, though, that until the current deficit is fully eliminated, an ASM aimed at maintaining financial balance would not make sense for the Social Security program. However, the international experience does offer a number of lessons for future reforms of the U. S. retirement system.
\end{abstract}




\section{Introduction}

As the baby boom generation enters retirement, a long-forecast funding crisis of the Social Security system is about to become a reality. Program outlays began to exceed tax revenues in 2010, reversing the cash flow from Social Security that had helped to fund other government programs for the past quarter-century. The projections of the 2011 trustees' report suggest that the system can remain solvent until 2036 by drawing on its reserves. Without legislative action, the trust fund is projected to be exhausted after that date, and benefits will have to be cut by about 25 percent to remain within the limits of expected revenues. Many other high-income countries are faced with similar financial problems with their public pension systems. Some of those countries have adopted legislative measures to reduce their funding deficits, and a few have included automatic adjustment mechanisms by which staged adjustments would be made in either benefits or revenues without the need for new legislation.

The objective of this paper is to review the experience of other high-income countries who have adopted automatic adjustment mechanisms as part of their efforts to maintain fiscal solvency in the presence of an aging population. What types of mechanisms have been adopted? Have they been sustained or eroded and reversed over time? Have they led to significant reductions in current and future imbalances between public pension revenues and expenditures? Can we draw any conclusions about the applicability of automatic adjustment mechanisms to the United States in light of the experience of these other countries?

We begin with a brief outline of the financial condition of the U.S. system. That is followed by a general explanation of automatic stabilizer mechanisms and the economic and political rationale that have led some countries to adopt them as part of a process aimed at restoring and maintaining financial balance in the public pension system. We turn next to a more detailed discussion of the experience of four other high-income countries that have utilized some elements of automatic stabilizers in the redesign of their pension systems. We follow that with a concluding discussion of the relevance of their experience to public pension policy in the United States.

\section{Social Security's Finances}

The basic Old Age, Survivors, and Disability Insurance (OASDI) system is relatively straightforward. Benefits are determined in four steps. First, a worker's taxable earnings in each year prior to age 60 are adjusted upward for growth in the economy-wide average wage index 
(AWI) since that year, and those indexed earnings are used to compute the worker's average indexed monthly earnings (AIME) as the average of the 35 highest years prior to the year of retirement. The wage indexation implies that workers born in the same year all receive the same percentage improvement in pensions regardless of whether they have high, average, or low lifetime earnings. Second, the benefit formula is explicitly re-distributional as workers with low lifetime earnings receive a primary insurance amount (PIA) that is a larger share of their AIME. ${ }^{1}$ Third, the benefit is actuarially reduced for those who retire before the full retirement age and increased for those who delay. Age 62 is the earliest date of retirement and no benefit increase is provided for those who delay beyond age 70. Finally, once workers initiate benefit payment, future benefits are adjusted annually for price inflation.

The AWI is also used to adjust the annual limit on taxable wages and other elements of the formulas for initial benefits. The OASDI tax rate has been constant at 12.4 percent of taxable wages since 1990, but there is a secular decline in the ratio of taxable to covered earnings due to the widening of the earnings distribution: an increasing portion of covered earnings is above the taxable maximum. This negative trend has been partially offset on the revenue side by allocating a portion of the income tax on OASDI benefits back to the fund.

A summary of the system's financial balance out to 2086 is shown in figure 1 . The cost rate includes benefit payments and administrative costs and is scaled by taxable earnings. The cost rate has been largely free of trend for the past 30 years, except for a large jump in the financial crisis of 2009. As the baby boom generation retires, however, the cost rate will rise rapidly from today's 13.4 percent of taxable wages to 17 percent in 2035, and then again level out in future years. Income is composed largely of contributions and income taxes on scheduled benefits. Thus, the income rate is projected to remain constant at about 13 percent of taxable earnings. For a period of time, the deficit will be covered by interest income and the drawing down of the trust fund, but the intermediate assumptions of the 2011 Trustees' report implies exhaustion of the reserves by about 2036. At that time, benefit payments will have to be slashed by about 25 percent to stay in line with available revenues. The annual funding deficit relative to

\footnotetext{
${ }^{1}$ The PIA is 90 percent of the AIME below a first break point equal to about 20 percent of the average AWI, 32 percent of the average AIME above the first bend point up to a second bend point equal to about 120 percent of the average AWI, and 15 percent above that level up to the taxable wage ceiling of 260 percent of the AWI. In addition, the AIME is recomputed using nominal earnings for working years after age 60. However, the PIA remains on a base of age 62 and is indexed for price changes up to the year of retirement.
} 
scheduled benefits will exceed 25 percent and rise toward 33 percent in future years. Under an assumed 75-year forecast horizon, the actuarial deficit is projected at 2.2 percent of payroll. $^{2}$

In response to a funding crisis in the early 1980s, Congress acted to close a projected OASDI funding gap. The contribution rate was increased from 8 percent to the current level of 12.4 percent by 1990, and the full retirement age was raised from 65 to 67 for successive birth cohorts from 1938 to 1959. Those actions were sufficient to restore the system to actuarial balance over a 75-years horizon. However, because the pattern was one of large surpluses in the early years and progressively larger deficits in the later years of the projection, the simple passage of time guaranteed that the system would move back into actuarial deficit (Aaron, 2011).

An alternative and somewhat surprising perspective on the financing difficulties of the system is provided by noting that new enrollees already pay a contribution sufficient to cover the costs of their future retirement. Instead, the unfunded debt of the system is the result of past decisions to pay earlier retirees a benefit far in excess of their contributions. By using the contributions of successive future participants to pay those benefits, the system's assets and interest income have been far smaller than would be the case under a fully-funded system. Rates of contribution were increased to a level sufficient to pay future benefits only for the cohorts born after about 1935 (Leimer, 2007). As a result of these decisions, the unfunded liability will continue to grow until all those pre-1935 cohorts with lower contribution rates have died. In this sense, the debts of Social Security are sunk costs or what has been called 'legacy debt' (Diamond and Orszag, 2004). Since those earlier payments reflect a collective decision of the country, it is not evident why future workers should be charged with the full burden of paying the resulting debt. But, in any case, the objective should be to either repay the debt on a steady basis or more relevantly to stabilize it as a share of the system's income.

In summary it is evident that Social Security's projected financial difficulties are real and addressing those difficulties sooner rather than later would make rational reforms easier and more likely. Under current law, waiting until the trust fund is exhausted would result in a sharp 25 percent reduction in benefits to all retirees in order to stay within the limits of annual

\footnotetext{
${ }^{2}$ The actuarial deficit can be viewed as the level of additional resources that would be required to close the deficit over the next 75 years and leave the fund with a precautionary balance equal to one year of expenditures. It has steadily grown from an estimate of balance after the 1983 reforms, and will continue to do so in the future, albeit at a diminished rate. It reflects the fact that the cash flow deficit is larger in the distant years than in the early portion of the projection period.
} 
revenues. Benefit reductions of the required magnitude would be enormously disruptive and politically unlikely. But, even before depleting the reserve, the Congress needs to be concerned about the implications of funding the repatriation of the trust fund reserve through the issuance of additional public debt. Despite its classification as a separate retirement fund, the OASDI reserve was effectively borrowed to finance other current expenditures, and policymakers focused on the overall budget in their decision making. Drawing down the trust fund to finance benefit payments will expand the size of the overall budget deficit and the magnitude of required public debt issues. Both the abruptness of the benefit cut associated with exhaustion of the fund and the impact on the overall budget suggest that the notion that the United States can afford to wait to address the funding problems of Social Security is an illusion.

\section{Automatic Stabilizer Mechanisms}

Versions of automatic stabilizers (have been an element of the U.S. pension system for many years. As described above, wage and price indexation of the earnings tax base and benefit payments have been a standard feature of the retirement system for the past four decades. The measures have been adopted in order to stabilize the share of earnings subject to taxation and to maintain the real value of benefits without the complexity of frequent legislative interventions. Indexation that protected the real value of benefits also lowered the risk that there would be political "bidding wars" during election years to appeal to older voters by increasing the real value of benefits (Weaver, 1988).

Mechanisms explicitly designed to stabilize the financial balance of the pension system are generally of more recent origin. Adverse demographic shifts and slower economic growth in many countries since the early 1970s have combined to force reductions in the scale of pension commitments and increases in pension revenues. Politicians have sought means of achieving these loss-imposing changes in ways that also minimize the political risks. They have employed two distinctive strategies in doing so. Most commonly, they have adopted specific legislative changes, but with significant lags and staged implementation of the changes. The Social Security Act of 1983, for example, included changes in the standard retirement age that did not begin to phase in until 2000 and will not be fully phased in until 2022. Similarly, Germany enacted a law in 2007 that will increase the standard pension eligibility age from 65 to 67 between 2012 and 2029. 
Automatic stabilizer mechanisms (ASMs) provide a second means of rebalancing retirement income systems. These mechanisms do not specify the exact dimensions and timing of policy changes through advance legislation. Instead, system parameters are adjusted over time without further legislative action according to movements in actual or projected changes in demographic indicators (e.g., life expectancy), economic performance (e.g., growth in the economy, which indicates capacity of the economy to pay benefits), or the financial status of the pension system (e.g., projections of impending insolvency). For example, Sweden’s automatic balancing mechanism, enacted as part of a broader pension reform between 1994 and 1998, adjusts pension benefits based on both life expectancy and performance of the Swedish economy.

\section{Structure of ASMs}

Automatic pension stabilization mechanisms differ on several key design parameters.

1. Certainty- based versus projection-based triggers: Certainty-based mechanisms adjust in response to actual changes in factors such as the ratio of employed workers to retirees in the most recent year. Projection-based triggers make adjustments based on expected future trends on dimensions such as life expectancy, fertility, labor force participation, and real wage growth that influence the financial solvency of a pension system over some specified period.

Each of these mechanisms has distinctive advantages and disadvantages. Projectionbased mechanisms rely on assumptions about future events that may or may not be accurate; yet, small changes in the assumptions sustained over a long projection period can result in the need for large and disruptive changes in future pension payments. Moreover, there may be a greater political temptation to interfere in the assumptions and projections to avoid triggering benefit cuts or tax increases during an election year. Certainty-based mechanisms based on real data have their own problems, notably a high degree of volatility. ASMs that link benefit adjustments to the ratio of workers to retirees, for example, may be affected by short-term fluctuations in unemployment. An improving employment situation, for example, might lead to a short-term rise in the ratio of workers to retirees, even when the long-term trend in the worker-retiree ratio is expected to deteriorate markedly. Some of these concerns can be addressed by averaging the indicators over a number of years.

2. Frequency of review: Countries that have annual reviews (and at least in theory, adjustments) of their pension systems are likely to require smaller adjustments with each review, 
making those adjustments less visible — for example, requiring only a freezing of benefit indexation rather than nominal benefit cuts. Lower visibility presumably makes such adjustments more politically feasible. On the other hand, annual adjustments raise the spectre of repeated conflicts and will inevitably collide with elections, giving opponents of those adjustments more political leverage to block them. Very infrequent reviews, such as the once-a-decade review incorporated in Italy’s 1995 reform (Franco and Sartor, 2006), could mandate very large cutbacks that will in turn create huge political resistance.

3. Degree of automaticity: Politicians may bravely pledge to commit future politicians (or themselves) to allowing unpopular adjustments to occur at some unknown future date, but they may be sorely tempted to renege and claim credit for preventing those unpopular benefit cuts or tax increases when the time actually arrives. Adjustment mechanisms could in theory be protected by procedures that require legislative supermajorities or other hurdles stronger than those found in the normal legislative process. At the weaker end of the spectrum are "alarm bell" provisions which make sure that an issue receives some attention but do not require substantial action by governments. The annual report of the Social Security trustees in the United States is a very weak "alarm bell”- -it calls attention to the long-range funding shortfall, but government is not even required to explain its inaction, let alone present a plan for addressing it.

4. Incidence of loss-imposition: Who bears the costs of automatic adjustment mechanisms depends especially on:

(1) the balance between expenditure reductions and revenue enhancement provisions in an automatic adjustment package;

(2) whether triggered cuts on the expenditure side are targeted at future retirees (e.g., automatic increases in standard retirement ages as the population ages), current retirees (e.g., cutbacks in indexation of benefits for the currently retired) or some combination of the two; and

(3) whether and how low-income workers and retirees are protected against cutbacks.

On the revenue side, automatic adjustments can be made to payroll tax rates, upper earnings thresholds for social security taxation, or both. Adjustments can also be made through some combination of benefits and revenues. Low-income retirees can be protected against cuts through changes in the benefit formula, a minimum benefit in an earnings-related program, or through creation of a separate means-tested program. 
The most comprehensive form of an automatic stabilization mechanism is what is known as notional or non-financial defined contribution (NDC) systems. Although many variants are possible, NDC pensions systems generally have the following characteristics:

- $\quad$ NDC benefit levels are based on earners' lifetime contributions to the system, unlike defined benefit systems, which in most countries are based on some smaller number of peak earnings years;

- $\quad$ Benefits of both current and future retirees are automatically adjusted for changes in life expectancy as well as some measure of wage growth or overall economic growth. If life expectancy increases, or the economy performs poorly, benefits for current and future retirees are adjusted downward until anticipated total payouts and resources are brought back into balance; $^{3}$

Payroll tax rates are permanently fixed, and general revenues cannot be used to pay benefits. Thus NDC pensions make any automatic adjustments exclusively on the benefit side;

- $\quad$ Like most defined benefit pension systems, they operate primarily on a Pay-AsYou Go (PAYG) basis rather than accumulating large balances. Sweden's system uses “buffer funds” from past periods of surplus to smooth spending across demographic peaks and valleys.

Shifting from an earnings-related defined-benefit pension system to an NDC-based pension system may have particularly important redistributive effects. In particular, such a shift may have severe consequences on individuals with interrupted and part-time participation in labor markets—characteristics that are especially associated with female workers.

\section{Economic and Political Rationales for ASMs}

There are both economic and political advantages to using phased adjustments and automatic stabilizing mechanisms to address funding problems and rebalance retirement income systems. From an economic perspective, workers need to plan their own retirement, and they would benefit from early knowledge of the magnitude of the pension that they can realistically

\footnotetext{
${ }^{3}$ The exact calculation of these amounts can vary. In Sweden, the initial benefit includes an imputed rate of return based on expected real annual wage growth of 1.6 percent, giving retirees a higher initial benefit than would otherwise be the case. If real wage growth equals 1.6, full price indexation occurs. If real wage growth is higher or lower than this standard, inflation adjustments in the retirement annuity are adjusted upward or downward accordingly. See Palmer, 2002, pp. 176-177, and Settergren, 2001.
} 
anticipate and the implications of differing retirement dates. One objective of any reform ought to be inducing workers to change their behavior and retirement plans as a means of mitigating the costs to them of the scaling back of benefits or increasing their contributions. Early knowledge of future changes can be provided by ASMs, but only if the triggering mechanism is forward looking and consistent with a phased introduction of the changes in program parameters prior to retirement. In addition, the complexity and opacity of most public pension systems makes it important that there be effective signaling - that is, that the implications of pension policy changes be clearly communicated to and understood by workers if they are to adjust effectively.

Most proposals for changes in benefits exclude the currently retired, presumably on the basis that they have limited means to adjust to benefit reductions. Yet, it is also difficult to implement large benefit changes between successive cohorts of new retirees. Under current Social Security law, the real value of new pension awards rises in line with the economy-wide wage rate - an inflation-adjusted real growth of about one percent per year. Legislating a reduction in the real value of the pension to successive cohorts in excess of that one percent would create large equity challenges (as well as political challenges). New retirees would receive a real benefit less than that of prior cohorts of retirees, creating a political grievance similar to the "notch baby" debate that has continued to plague the discussion of Social Security reform since the 1970s. Hence, a phased adjustment aimed at holding the real value of new benefit awards constant for a period of time may define a practical limit on the pace of benefit reductions. Similarly, an automatic adjustment that takes gradual effect may minimize equity concerns about treatment of adjacent cohorts of retirees.

The economic argument in favor of a phased or automatic adjustment of the tax rate may be less compelling, but adjusting contributions prior to a cohort's retirement does introduce an element of prefunding into the system. Conversion to a fully-funded system by which each individual or cohort finances their own retirement would be extremely complex and offer limited benefits; it is more practical to suggest that future cohorts should pay a portion of any added cost of their own retirement. Thus, if the tax rate must rise in the future to pay the benefits of a particularly large cohort, moving a portion of the tax change forward can smooth the adjustment.

A political rationale is often given for phased adjustments and automatic stabilizing mechanisms as well. Because of population aging, retirement policies are bound to be focused 
on the scaling back of pension promises. Benefit reductions and contribution increases are painful; they offer few political rewards and risk substantial punishment from voters and powerful interest groups. Moreover, there is a connection between the demographic challenge and the political challenge: as the population ages, so too does the electorate. As the share of voters who are retirees and near-retirees grows, pension issues rise in salience and the opposition to near-term cuts is likely to increase. Hence politicians will seek to delay the onset of negative changes - preferably to a time beyond their term in office - and have them take effect gradually. They also frequently use "stealth" mechanisms that are difficult for voters to understand, such as changes in indexation mechanisms and increasing the number of years worked that are needed to qualify for a "full” pension benefit. ${ }^{4}$ Even lagged, phased, and stealthy pension reforms run the risk of producing identifiable losses that can be used by a government's political opponents. Once politicians put in place mechanisms that make unpopular adjustments automatically, they can induce change without the need to "get their hands dirty."

\section{How Sustainable Are Automatic Stabilizing Mechanisms?: Theoretical Considerations}

International experience with automatic stabilizing mechanisms in public pension systems can inform several aspects of U.S. debates. First, knowledge of those experiences can highlight potential political conditions or strategies that might make it more or less likely that ASMs could be adopted in the United States. After all, while adoption of ASMs offers the potential to avoid blame for future pension cutbacks, it may produce blame in the short term in the decision to adopt an ASM. This is especially true when that mechanism appears likely to be triggered and produce painful cuts in the near term. The United States, with its highly polarized legislative politics, multiple veto-point legislative process, powerful and resourceful interest groups, and multiple sources of expertise (which is likely to lead to increased transparency on the impact of an ASM) would seem to be a poor candidate for any policy innovation that requires a broad consensus across parties and interests, but other political systems that operate with a high degree of inter-party consensus have adopted ASMs. Second, knowledge of international experience can highlight problems that may arise in the implementation process, such as difficulties in developing accurate projections of the magnitude of future pension funding burdens, or pressure from politicians on statistical agencies not to make projections that would

\footnotetext{
${ }^{4}$ Politicians may also employ other mechanisms to reduce blame by voters, such as reform processes that share responsibility across political parties.
} 
trigger politically unpopular benefit changes — especially as an election is approaching. Understanding problems that may arise during implementation and how other countries have dealt with them may be useful in preventing a recurrence if such provisions are adopted in the U.S. Finally, international experiences can illuminate potential threats to ASM's political sustainability: are politicians or social interests likely to seek to erode automatic stabilizing mechanisms after they have been enacted or simply abolish them? And if so, under what conditions are efforts to undermine ASMs likely to earn serious consideration from policymakers? Do these efforts succeed or fail? And what sorts of changes to ASMs are likely to be made?

We will focus here on the sustainability problem, first outlining some general expectations about the political sustainability of ASMs suggested by social science theory and then turning to the experience of particular countries. Recent work by Eric Patashnik (2003, 2008) and others has highlighted the vulnerability of many policy reforms to reversal or erosion. Having an automatic stabilizing mechanism in place does shift the bargaining leverage in favor of those who want those adjustments to occur as scheduled, because preventing the mechanism's reversal or erosion requires them merely to block changes proposed by others. This advantage is likely to be important (1) in political systems where the governing party or coalition has sufficient agenda control to keep reform-eroding proposals off the agenda, and (2) in systems with multiple veto points, where super-majorities are usually needed to move from the default position. But where agenda control is weak and where veto points are fewer and weaker, temptations for politicians to prevent visible loss-imposition on present and future retirees will remain strong. The U.S. is a system that has multiple veto points but also weak agenda control: unless leaders of both parties agree to keep an issue off the agenda, it is difficult to do so. Thus a measure that would prevent or delay the triggering of cutbacks from an ASM might be very difficult for politicians in the U.S. to resist if that triggering event appeared to be imminent. Economic downturns, which may trigger a short-term government fiscal crisis as well as lowering contributions to a pension system, are likely to be contributing conditions to any challenge to an ASM that is already in place, because the benefit cuts triggered during a downturn are likely to be more visible than during good times, and tax increases will be opposed as weakening the recovery. 
In the presence or expectation of a loss-imposing ASM triggering event, action by politicians to weaken that impact is more likely when an election is anticipated soon, and the party or parties controlling government has low “electoral slack" - that is, there is a credible threat that they will lose the election. Given the short (two-year) electoral cycles for the U.S. House of Representatives, modest margins of party control in Congress, and candidate-centered elections that offer candidates little protection from voters' wrath if they back the party line on a measure unpopular with voters, virtually any ASM triggering event of significant magnitude would likely lead to an effort to weaken the impact of losses imposed by the ASM. ${ }^{5}$

Whether such initiatives succeed, however, also depends upon how insulated the automatic stabilizing mechanism is from change once it is the default position. As discussed above, highly automatic procedures, especially those where modifications or overrides require approval by legislative super-majorities and navigation of multiple veto points are most likely to survive intact. Political systems in which major parties have high capacity to engage in sustained cartelistic behavior are also more likely to keep ASMS from being eroded, as are systems where ASMs have been adopted as part of austerity packages negotiated with external actors (e.g., the International Monetary Fund or the European Central Bank) and where those actors exercise a high level of external oversight and enforcement.

Even when faced with a triggering event, politicians are likely to be reluctant to abolish ASMs already in place entirely, given the significant investments of time and political capital that are required to put them in place in the first place and their long-term blame-shielding advantages. And in an era of nervous capital markets, abolishing an ASM might be perceived as a sign of eroding commitments to control budget deficits. A full reversal of automatic adjustment mechanisms is probably most likely when there is a turnover in the party that controls the executive and the legislature, and a party that was never committed to that mechanism takes over the reins of power.

Modifications to ASMs can take several forms. These can be roughly categorized as:

Manipulation: the ASM remains intact, but data are manipulated to avoid the triggering event or weaken its impact;

\footnotetext{
${ }^{5}$ In multi-party parliamentary systems, other conditions, such as the entry of new parties that are not committed to the ASM into party competition or into a governing coalition would also make it more likely that challenges to the ASM would reach the agenda, but these conditions do not apply to the stable two-party system in the United States.
} 
Evasion: the ASM remains officially intact, but other policy changes weaken or eliminate its impact on pension incomes-for example, increases in another pension tier or cuts in taxation of pension benefits;

Suspension: the ASM is "temporarily" suspended or postponed when it would trigger politically costly changes. This delay may be either indefinite or for a specified period-for example until after the next election;

Erosion: Politicians can change an ASM permanently in ways that undercut its effects. Such modifications might include, for example, a shortening of a projection period, a shift from a full to partial adjustment for adverse demographic trends, or an exclusion of politically-sensitive groups from its effects.

Overall, across the range of democratic political systems, we would expect to see (1) little outright repeal of ASMs once they are in place; and (2) little manipulation of ASMs in political systems with substantial professionalization of bureaucracies and governmental transparency; but (3) substantial evasion, suspension and erosion of ASMs- especially when they are about to be triggered and in the run-up to elections, and especially in political systems with few institutional veto points.

\section{International Comparisons}

The U.S. challenge of financing the transition of the baby-boomers into retirement is modest compared to the demographic challenge faced by most other high-income countries. The ratio of the population over age 64 to the population age 20-64 is projected to remain below that of the other G-7 countries and the OECD average. Among the G-7, the United States has the highest fertility rate and the lowest life expectancy, both of which are helpful to maintaining a low pension cost. It also has one of the more modest pension programs as measured by the benefits that it provides.

There are two basic measures of pension benefits. The first is the replacement rate: the value of the annual benefit relative to individuals' earnings in their working years. The second is pension wealth: a stock measure of the present value of lifetime pension benefits. Most public discussions focus on the replacement rate; but pension wealth is the more relevant concept for evaluating the financial condition of the pension system because it reflects both the replacement rate and the expected number of years for which the pension will be paid. Both of those 
measures are reported in Table 1 for the United States the other large G-7 countries, and Sweden. The United States, Japan, and the United Kingdom have relatively modest benefit levels compared to those of France and Italy. In addition, countries differ considerably in the progressiveness of their benefit structure, with Canada and the United Kingdom being the most redistributional.

Other high-income countries have utilized a variety of automatic stabilizing mechanisms, notably Sweden's comprehensive NDC system. These mechanisms are generally used in contributory systems where at least a rough balance is anticipated over time between contributions and payouts. In the following sections, we review the experience of four countries with pension reforms that embodied elements of ASMs: Canada, Sweden, Germany, and Italy.

\section{Canada}

Canada has a complex public pension system in which multiple tiers play a significant role. It has both a large quasi-universal (benefits are “clawed back” for very high income individuals) flat-rate pension tier, known as Old Age Security (OAS) and a large income-tested tier, called the Guaranteed Income Supplement (GIS). Both of these programs are financed through general revenues. In addition, the Canada Pension Plan (CPP), a contributory social insurance plan pays benefits linked to an individual's contribution history. An opting-out clause allows Quebec to operate a distinct Quebec Pension Plan (QPP) in that province, with contribution rates and eligibility and benefit levels in the CPP and QPP kept harmonized.

The financial condition of the CPP was deteriorating by the 1980s as a result of declining economic and demographic conditions, a number of benefit enhancements enacted in the 1970s, and a dramatic increase in take-up of disability benefits (the CPP provides disability as well as retirement and survivors benefits). The CPP's Chief Actuary estimated in 1995 that the CPP trust fund would be exhausted by the year 2015, and that with an empty trust fund, the contribution rate needed to finance contributions on a pay as-you-go basis would have to rise from 6 percent to 14.2 percent by the year 2030 (Office of the Superintendent of Financial Institutions, 1997).

Despite these financial problems, the difficulty of securing provincial assent helped to keep CPP cutbacks from even getting on the agenda for a number of years. Declining trust fund balances, eroding public confidence in the CPP, and growing awareness that a failure to address the CPP's problems quickly would lead to soaring contribution rates in the future finally led to an initiative by Ottawa in 1995 to alter the program (Federal/Provincial/Territorial CPP 
Consultations Secretariat, 1996; See also Prince, 2003; Little, 2008). Ottawa and eight of ten provinces reached agreement in 1997 on a package of CPP changes, implemented in 1998, that distributed pain among all parties.

The most visible change in the CPP rescue package--and the one with the biggest fiscal impact--was in payroll taxes (see Slater and Robson, 1999). Tax rates on employers and employees rose from 6 to 9.90 percent (shared equally between the two) over a six-year period to finance a move away from Pay-As-You-Go toward partial advance funding of the CPP. ${ }^{6}$ Little noticed at the time the legislation was passed, the new CPP legislation also put in place a new "default" or fail-safe procedure for ensuring the long-term financial viability of the CPP. In the future, the chief actuary for the CPP was to prepare triennial estimates of the long-term (75-year) financial sustainability of the Plan. If an actuarial deficit emerges, Ministers from Ottawa and the provinces are supposed to agree within the year on any needed changes to keep the plan viable; if they do not agree, contribution rates will increase automatically to meet half of the anticipated deficiency (phased in over three years), and price indexation of all benefits will be frozen for the next three years. ${ }^{7}$ This procedure could be overridden by Cabinet order, but it would take affirmative action to do so.

The revised statute created a strong procedural presumption that the CPP would be kept fiscally sound: its fail-safe trigger kicks in when the long-term viability of the plan is in question, not just when the plan is in immediate danger of not being able to pay out benefits. Moreover, the pain of a future CPP fix will be shared equally between workers (through contribution rate increases) and current beneficiaries (through benefit freezes) unless federal and provincial finance ministers can agree on an alternative. The "clean hands" default procedure established by the statute allows losses to be imposed on beneficiaries and contributors without politicians having to do anything--although the concentration of accountability in Canada's Westminster

$6 \quad$ The initial tax increase was not scheduled to be felt until 1998, after the next federal election.In fact, the initial tax increase, from 5.85 to $6.0 \%$ of payroll, was retroactive to January 1997, but was not to be paid until income tax time in the spring of 1998 (Ferguson, 1997). Cuts in CPP retirement benefits were, not surprisingly, made much harder for beneficiaries to discern and understand. Just over one quarter of the reduction in the overall projected long-term 4.0 percent of payroll in the CPP/QPP contribution rate required to achieve long-term funding stability came on the benefit side, largely through technical changes to formulas that are almost incomprehensible to most beneficiaries. For a summary of the financial impact of the benefit changes in the 1997 CPP reform package, See Office of the Superintendent of Financial Institutions, Office of the Chief Actuary, 1997, pp. 6-8.

${ }^{7}$ See Canada Pension Plan, Chapter C-8, Consolidated Statutes of Canada, sections 113-115 and Statutes of Canada, Chapter C-40 (Bill C-2), sections 94-6, and Slater and Robson, Building a Stronger Pillar, pp. 6-7. 
political system means that there would be pressure on a future Cabinet to avoid blame for loss imposition by cancelling contribution increases and indexation freezes.

A final impact of the new statute was that by turning the highly inexact science of longterm actuarial projections into a policy trigger for imposing painful increases in contribution rates and indexation freezes, it increased the probability that those projections would be the subject of future political conflict. And shortly before the first report was due under the new law, the Chief Actuary was fired. The fired Chief Actuary, Bernard Dussault, charged that he had been pressured by Finance Ministry officials to change his assumptions after preliminary estimates suggested that a small ( $0.1 \%$ of payroll) increase in the contribution rate would be needed to keep the CPP solvent in the long term. The Chrétien government argued strongly, if not very convincingly, that Dussault's firing had nothing to do with his conclusions (Eggertson, 1998; Jack, 1998a and 1998b; Jack, 1999; see also the discussion in Little, 2008).

The consultant commissioned to complete Dussault's report, using a set of assumptions that were questioned by some critics as too optimistic, produced a report showing that the system was in fact slightly ( $0.1 \%$ of payroll) over-financed. The issue soon faded, however, and later actuarial reports, which have shown the system in surplus at the end of the 75-year projection period, have not spawned controversy. Nor have Canadian politicians faced a "when push comes to shove" situation of being forced to let unpopular benefit cuts and payroll tax rate increases go into effect.

Canadian experience thus suggests several lessons on the sustainability of automatic stabilizing mechanisms. The hints of possible political interference in the first actuarial assessment of CPP suggest that manipulation of ASMs is a real risk, although nothing comparable has occurred since. The Canadian experience also suggests the not very surprising lesson that if a mechanism is not activated (and thus never produces visible losses), it is unlikely to spark opposition that leads to its reversal or erosion.

\section{Sweden}

Sweden is often seen as the quintessential welfare state. ${ }^{8}$ The Social Democratic Party, which was in power (though usually in a minority government or in coalition) for all but nine years of the period from 1932 to 2006, was the guiding force shaping expansion of the Swedish

$8 \quad$ The Sweden case study draws on collaborative work with Karen Anderson. 
welfare state. By 1970, the public pension system in Sweden consisted of three tiers. A flat-rate basic pension (folkpension) operated on a Pay-As-You-Go basis. An earnings-related national supplementary pension was partially pre-funded. Both tiers were financed largely by earmarked employer contributions. A means-tested pension supplement financed from general revenues provided a higher pension floor for those whose earnings-related benefits were very low. The pension supplement, in combination with the other two tiers, moved almost all seniors in Sweden out of poverty (using the standard OECD relative poverty measure).

By the 1980s, several problems with the Swedish pension system were becoming evident. Funding the pension system through payroll taxes was becoming increasingly problematic due to slower economic growth and an aging population. Successive Swedish governments responded to the pension crisis through a combination of ad hoc measures and efforts to bring about more fundamental changes that would stabilize financing and benefits for the long term and therefore keep pensions from becoming a recurrent (and divisive) item on the policy agenda (see Anderson and Immergut, 2007: 367-372).

To plan for fundamental reform, a pension working group comprised of members of four centre-right parties and the Social Democrats (but not the smaller Left or New Democracy parties) was created. The group issued their first report in August 1992, including a sketch of proposed principles for reform; a comprehensive report was issued in 1994. The working group continued its work after the Social Democrats returned to power in September 1994, and most of the implementing legislation was enacted by 1998.

The new pension system has several major characteristics, including a permanently fixed contribution rate of 16 percent for the earnings-related pension, the addition of a relatively modest (2.5 percent of payroll) mandatory defined-contribution tier, and a new income-tested "guarantee pension" financed from general revenues that would take over most of the burden of redistribution within the pension system. ${ }^{9}$ For our purposes, however, the key change was replacement of the former flat-rate pension and earnings-related pension by a new "income pension” based on what came to be called Notional or Non-Financial Defined Contribution (NDC) principles. With the NDC, no promises are made about the level of benefits in relation to an employee's final salary or to the level of income for a specific number of earnings-years.

\footnotetext{
${ }^{9}$ The guarantee pension requires far more resources than the pension supplement since it took over much of the function of supporting very low income pensioners who had previously received the flat-rate pension.
} 
Benefits are based on contributions (which may include contributions made on a person's behalf by the state, for example for periods of unemployment or child-caring) over the entire course of their working life. ${ }^{10}$

In terms of stabilizing pension system finances, the key feature of the new NDC pension tier is an "automatic balancing mechanism" that uses a complex formula to correct for increases in life expectancy and slow wage growth by lowering initial benefits (for those who have not yet retired) and benefit indexation (for retirees) until the system comes back into balance. The balancing mechanism allows reductions to occur without politicians having to take direct, visible actions, and generally accrue slowly over a long period of time. The new income pension also took over most of the "buffer funds" from the old earnings-related pension, and balances in individuals' notional accounts include a share of buffer fund balances as well as their own contributions. But because the balancing mechanism makes all corrections in the year after data is finalized (e.g., at the beginning of 2010 for changes that occurred in 2008), as well as demographic and wage growth trends, there is a potential for significant swings in benefits during periods where the value of buffer funds fluctuate.

The final pension reform package was sold as having the potential to yield a pension equivalent to that under the prior system —at least for those who worked steadily for forty years, if there were no further increases in life expectancy over that prevailing in 1994, and making optimistic but plausible estimates of overall economic growth (2 percent annually) and returns on the individual account tier included in the final package (Sweden, Ministry of Health and Social Affairs, 2002: 23; Settergren, 2003). However, projected life expectancy increases after 1994 made the idea that pension replacement rates would remain stable obsolete by the time implementing legislation for the new NDC pension was adopted.

Sweden's new retirement system moved away from a standard retirement age to a flexible retirement age between 61 and 67 . Swedish workers receive annual statements that project their future pension benefits under three separate retirement ages, as well as two projections of economic growth. These retirement income projections provide clear information about future benefits, but they do not present as clear a signal that individuals should work longer than previous cohorts as would an increase in the "standard retirement age" to avoid

\footnotetext{
${ }^{10}$ Pensions are indexed to developments in real wages rather than prices.
} 
receiving "reduced benefits.” Nor is it clear how much attention workers pay to projections about different rates of economic growth.

One notable feature of Sweden's implementation of its new pension system is that the pension working group established to design the system has been maintained in a modified form after the new system was established. This mechanism facilitates resolution of conflicts as new issues arise during implementation. Equally important, it helps to sustain commitment to the pension system and to collaborative solutions when problems arise.

The most serious problem that Sweden has faced in implementing its "automatic balancing mechanism” arose with the worldwide financial crisis and recession that began in 2008 (see Kruse, 2009; Settergren, 2010). Sweden's NDC pension system is particularly vulnerable to disruption because the solvency of the system is calculated based not only on the basis of economic growth and life expectancy, but also on the value of accumulated contribution surpluses that are held in five "buffer funds." These funds invest heavily in volatile investments in Sweden and overseas. The financial crisis and recession led to a decline in the value of the assets held by those funds of 194 billion kronor at the end of 2008, or more than 21 percent. This was expected to lead to a 3.3 percent reduction in income pension benefits in 2010, though low income retirees would be protected by an increase in the guarantee pension (Forsäkringskassan, 2009: 43.). Would the stabilizing mechanism hold up under such pressure, especially with a general election scheduled for September 2010?

A former Social Democratic Finance Minister suggested injecting 200 billion kronor in general revenues into the pension system to prevent triggering the "brake," asking "are the five parties behind the pension arrangements ready to go to the polls on this, with all the opportunities for other parties — inside and outside parliament - to propose measures that would seem far more attractive to 1.6 million pensioners?” (Åsbrink, 2008). Sweden’s Minister of Social Affairs suggested additional possibilities, including compensating retirees from the state budget. After receiving expert input from the Swedish Social Insurance Agency, the matter was referred to the multi-party working group representing the five parties that had agreed to the original 1990s pension reform package. The working group agreed to a change that would base the activation of the automatic balancing trigger on buffer fund balances averaged over three years. Thus, any benefit cuts that are based on swings in the buffer fund balances will be moderated over time- - phasing in more slowly, but also rebounding more slowly during stock 
market upturns. In addition, the government reduced taxation of pension benefits so that very few pensioners would experience a cut in their nominal net (after tax benefits).

Overall, the experience of the first major "pothole" of the Swedish NDC system suggests a mixed verdict on its political resilience. The five parties that belong to the pension group rejected the Swedish Social Insurance Agency's recommendation on how to make the automatic balancing mechanism less volatile, but the change that they endorsed is consistent with the principles of their original agreement rather than an erosion of the ASM because it does not inject new money into the system. The change in taxation, however, is clearly an evasion of the intent of the ASM which all of the major parties endorsed in the lead up to the 2010 election. Thus, the multi-party "cartel” backing the NDC system remains intact. Its automatic balancing mechanism, while modified in details, remains largely unchallenged in its broad principles.

\section{Germany}

Germany, like Sweden, has a long-established public pension system (See for example Hering, 2008; Anderson and Meyer, 2003; Hinrichs, 2005; Schulze and Jochem, 2007; Busemeyer, 2005, Schludi, 2005; Jacobs, 2009). Germany’s system differs from Sweden's in having relied almost exclusively on a single contributory social insurance tier for its public pension system. But Germany has faced a particularly serious demographic challenge of a rapidly aging population. German reunification exacerbated the financing pressure on the pension system as inefficient East German industries were shut down and many of those workers took early retirement. By the late 1990s, contribution rates were approaching 20 percent, and were expected to rise much higher in the future if no action was taken. Moreover, Germany's pension system is financed in part by federal government subsidies from other revenue sources (notably the VAT and more recently ecology taxes); these expenditures were also growing, putting an added strain on the general budget. ${ }^{11}$

Germany's demographic and financial challenges have been exacerbated by a series of political challenges, notably a changing party system. Germany's long-standing "two and a half" major players (the Christian Democrats/Christian Social Union, Social Democrats, and Free Democrats) were joined successively by the Greens in the 1980s and the Party of Democratic Socialism (later Left Party, Die Linke) in the 1990s. The PDS positioned itself as an intransigent

11 In 2007, the federal grant covered 28.5 percent of the expenditures of the pension insurance system (Deutsche Bundesbank, 2008) 
defender of the welfare state status quo, and was seen as “uncoalitionable” because of its Communist past: this freed it from concerns about the practicalities of governing. These changes made it more difficult to build a broad cross-party consensus in favor of proposals that would cut back on spending commitments - especially for the SPD, which now faced a credible party challenger on its left. Equally important, a more complex party system meant that maintaining commitment to any pension changes would also be more difficult once measures were in place and actual cutbacks were imminent because there were strong incentives to defect from any retrenchment-supporting party cartel in search of votes.

Changes in the party system not only complicated coalition building in developing policy proposals and passing them in the lower legislative chamber, the Bundestag, they also created more uncertainty in the Bundesrat, where the governments of Germany's Länder are represented. The Bundesrat has a veto over changes in the financing provisions of the pension system, although not provisions that relate solely to benefits. Because Bundestag elections are not synchronized with elections to the Länder, changes in the composition of the Bundesrat as a result of Länder elections could derail government pension financing initiatives unless broad agreement was reached across party lines. Moreover even governments in the Länder that mirrored the coalitional arrangements in the center could not necessarily be counted on to back such legislation proposals.

Responses to the German pension system’s demographic and financial crisis initially focused on increased financing (notably contribution rate rises) and then ad hoc benefit and eligibility cutbacks. This process was characterized by a broadly consensual approach in which social policy experts from the major parties as well as employers and trade unions formulated policy responses within a relatively closed and depoliticized policy network which "after a joint learning process, usually resulted in compromises acceptable for all actors involved.” (Hinrichs, 2005: 54; see also Hering, 2008).

By the mid-1990s, however, consensual policymaking had broken down under the strain of multiple pressures, notably slow job growth and increased take-up of early pensions as a result of firm closures in the former East Germany. The collapse of consensual pension policymaking in Germany was clearly evident in legislation enacted in $1997 .{ }^{12}$ The CDU/CSU/FDP coalition

12 For detailed discussion of the electoral calculations involved in the 1997 reform inside and outside the CDU/CSU/FDP coalition, see Schulze and Jochem, 2007, pp. 682-686. 
government headed by Helmut Kohl attempted to address the severe financial and demographic challenges confronting Germany’s pension regime by developing a comprehensive reform package. The Social Democrats, anticipating a federal election in 1998, refused to collaborate, so the governing parties proceeded on their own. The 1997 legislation included a "demographic factor" that would automatically lower benefits as life expectancy rose. Targets were also set for both near-term and longer-term caps on payroll tax rates.

Reflecting the more partisan atmosphere of pension policymaking in Germany in the late 1990s, the "demographic factor" was abolished after a new Social Democratic-Green coalition came to power in 1998, while proceeds from an eco-tax were dedicated to the pension system with the objective of stabilizing the contribution rate (Hering, 2008: 172). After a prolonged debate, a small new quasi-mandatory tax-advantaged and subsidized individual account tier was enacted in 2001 to compensate for planned future declines in public system replacement rates. At the same time, the new law introduced a "Riester factor" into the calculation of the benefits of both current and future retirees that ostensibly offsets the partial shift from public to private pension schemes (though this is of course purely fictitious for current retirees).

After a very narrow victory in the 2002 election, the Schröder Red/Green government also enacted a major pension reform in 2004 that included a new automatic stabilizing mechanism to replace the "demographic factor" that the SPD had revoked after coming to power in 1998. This new stabilizing mechanism was rebranded under the new label of "sustainability factor" (Nachhaltigkeitsfactor) to make it more politically palatable. It was also designed to lower replacement rates over time, stabilizing the contribution rate. However, in response to opposition from trade unions and the left-wing of the SPD, the impact of the sustainability factor was capped: it could not cause pensions for workers with a full earnings history to fall below a 46 percent replacement rate.

The main difference between the demographic factor and the sustainability factor is that the latter is based on the actual ratio of pension contributors to beneficiaries, while the demographic factor was based mainly on demographic projections. The sustainability factor does not just reduce pension benefits as life expectancy rises; but by being based on the ratio of contributors to beneficiaries, it incorporates developments in fertility, migration, and changes in labor force participation. There also was a political component to the decision to use a different form of automatic stabilizing mechanism: during the 1998 election campaign, the SPD had run 
on a platform of opposition to the demographic factor and presented itself as the party defending pensions. Having promised the electorate to undo the demographic factor, it would have been political suicide to have proposed the same mechanism when they were in power (Krupp, 1999). Overall, the debate over the sustainability factor was much more technical than the first one, mainly because all of the major parties except the PDS agreed that action needed to be taken. Thus, while Germany did not move as far in the scope of its automatic stabilizing mechanism as Sweden, it did put in place a mechanism that would facilitate automatic downward pension adjustments—so long as politicians could agree to keep their hands off.

Rather than putting pension benefits on autopilot, however, the new pension formulae was followed by several rounds of ad hoc policymaking. Most notably, in 2007 a CDU/CSU/SPD "grand coalition” enacted a gradual increase in the standard retirement (and thus the age for receiving “full” pension benefits) to 67 by the year 2029. In addition, keeping their hands off mechanisms that were intended to reduce pension spending proved to be politically impossible in the wake of the global financial crisis. With the 2009 elections approaching, the "grand” CDU/CSU/SPD government proved to be not so grand in its capacity to take shared blame for pre-scheduled cuts. On May $5^{\text {th }}, 2008$, the Bundestag passed the "Law to adjust pensions in 2008” which had the effect of increasing pension payments by 1.1 percent, instead of the 0.46 percent increase that would have resulted if the overall formula (wage growth plus the Riester and sustainability formulas) had been used without any adjustments. It also laid the basis for a more substantial increase in 2009, mainly by suspending the Riester Factor for two years 2008 and 2009. The coalition government stated that this was only a temporary suspension of the Riester Factor and the government is still committed to contribution rate caps described earlier (Lexis-Nexis, 2008). The overall costs of the measure were estimated to total 2.6 billion Euro in 2008 and 2009 (Suddeuutsche Zeitung, 2008).

The new law was supported by the grand coalition of SPD and CDU/CSU. The coalition argued that with this short-term measure pensioners could participate in the economic upswing, without jeopardizing the long-term sustainability of the pension system (Bundesministerium fuer Arbeit und Soziales, 2009). Another argument that was brought up by proponents during the debate was the fact that pensions had been increased by only very limited amounts in past years, while overall costs of life were rising (Focus, 2008). The entire opposition - FDP, Green Party, and the Left Party -voted against the law, but for differing reasons. The Left party criticized the 
increase as "not enough" and launched an (unsuccessful) plan to increase pensions by 4 percent, and abolish both the Riester and the sustainability factors. The FDP and the Green party, on the other hand, voted against it because the increase in pension payments would have to be covered by higher contributions by future generations.

Controversy over the pension funding formula continued in the spring of 2009, when pension payments increased by 2.41 percentage points in the East, and 3.38 in the Western Bundeslaender--the highest increase since 1994. The increase resulted from a number of factors in the pension adjustment formula, including a significant gross wage increase of 2.1 percent and the second year of the suspension of the Riester factor, which had already been set in 2008 as noted above (the two "suspended” years of the Riester factor will be restored in 2012 and 2013). But the pension rise was also fueled by a 0.3 percent increase in the sustainability factor as employment growth shifted the contributor/beneficiary ratio. This change shows the potential volatility of an adjustment formula that is sensitive to short-term changes in employment.

Chancellor Merkel and the grand coalition emphasized the importance of promoting spending in the global financial crisis and justified the increase in pensions as part of the German “stimulus package” (Der Spiegel 2009). Criticism came mostly from outside the coalition parties. As usual, the Left party criticized the increase as insufficient. On the other side, critics claimed that the suspension of the Riester factor for two years would lead to a contribution rate of 20.7 percent by 2016, much higher than the government originally estimated (Branstetter, 2009).

In short, while the major parties remain committed to principles of the sustainability index and adjusting pension spending to Germany’s changing demographic reality, they have not matched Sweden's success in achieving a durable cartel that cooperates in sustaining and supporting the operation of the automatic stabilizing mechanism. Conflict over the stabilizing mechanism and the associated Riester factor have become part of pension conflict in Germany rather than preventing pension conflict.

\section{Italy}

Through the early 1980s, the Italian pension system provided a classic illustration of an out-of-control and unsustainable Pay-As-You-Go pension system, with a fragmented collection of multiple pension schemes for different occupational categories, low retirement ages (60 for men, 55 for women) in the largest retirement scheme, and earlier retirement "seniority pensions" available with 35 years of work and contributions. A means-tested old-age benefit was available 
to resident citizens of limited means. Moreover, the absence of actuarial adjustment for early retirement created incentives to take the earliest possible retirement (for summaries, see Franco, 2006; Ferrera and Jessoula, 2005). Financing was through a combination of employer and employee payroll taxes, with state subsidies making up any shortfalls. This structure in turn reflected a political system in which appeals to narrow electoral constituencies were dominant and weak governments had severe difficulties in imposing losses on well-organized constituencies. The system's fiscal problems are exacerbated by demographic trends: Italians have long life expectancy and low birth rates. Thus, life expectancy after reaching pensionable age in 1993 was a staggering 24.2 years for men and 28.8 years for women-the highest in the OECD (OECD, 2011: 29-30).

A series of reforms in the 1990s (notably the 1992 Amato, 1995 Dini and 1997 Prodi reforms) were prompted by a combination of short-term budget concerns, need to meet the budget deficit accession criteria for the European Monetary Union, and projections that a massive (23.4\% in 2040) share of GDP would be consumed by pensions in the future (Ferrera and Jesoula 2005:31; Schludi, 112). Among other provisions, the reform packages rationalized the structure of pension systems across occupational groups, trimmed seniority pensions, raised retirement ages for both men and women, lowered the actuarial pension used in converting wage history into pension benefits, and created a new mechanism for funding supplemental defined contribution pensions. In addition, the reforms gradually-very gradually-converted the pension system from defined benefit to notional defined contribution principles, which increased incentives to delay retirement and reduced intra-generational inequities.

The new Italian NDC pension system is structured quite differently from the Swedish system. Workers in the Italian system are credited with contributions to their notional accounts equivalent to 33 percent of their wages (20 percent for the self-employed) which is slightly higher than actual contributions. Retirement age was originally set flexibly at between 57 and 65--though minimum account balances were required for early retirement and the minimum age was raised by later legislation. Conversion of the account balance into an annuity benefit at retirement was based on a conversion coefficient that incorporated both life expectancy and an imputed return on contributions. Unlike the Swedish system, however, where system parameters are adjusted annually, the Italian conversion coefficients were to be adjusted only once a decade to reflect actual trends in life expectancy and economic growth, and the statute does not require a 
particular formula for taking demographic change into account in periodic recalculations. Moreover, the imputed rate of return does not vary in response to actual economic performance, and pensions are not subject to revision once they have been awarded—all of the adjustment takes place on the part of new retirees. Nor does the NDC system have an automatic balancing mechanism that guarantees long-term balance as the Swedish system does (Franco and Sartor 2006: 470, 478).

An additional shortcoming of the Italian reform in terms of stabilizing pension expenditures is that many of the changes in the Italian system, especially those that affected the structure of benefit entitlement under the NDC reform, were heavily backloaded to affect mostly (or exclusively) younger workers: only those entering the workforce in 1995 and later years were fully subject to the NDC rules for awarding benefits, while those with more than 18 years of labor market experience were fully under the old benefit determination rules and those in between received pro rata treatment. The long transition reflects the very large role of older workers and pensioners within Italian labor unions, which have the political cloud to kill reform packages in which they do not acquiesce (Schludi, 2005:126, Anderson and Lynch, 2007). More broadly, the contentious and rushed nature of the reform process impacted later developments: "the nature of preparatory work was limited and very little information was provided to the public. This had negative implications both on the technical side (e.g. the self-equilibrating mechanisms are partial and slow) and on the political side (the lack of a broad consensus spurred the following governments to introduce a number of changes that were not consistent with the initial approach)." (Chłoń-Domińczak, Franco and Palmer, 2009: 6)

The 1990s reforms did substantially reduce long-term Italian pension liabilities. But a sizeable continuing structural deficit remained after the 1990s reforms), and a key parameter, the conversion coefficient, was subject to ad hoc revision once a decade. That revision must be made within a national context of continued intense fiscal stress (including Eurozone deficit and public debt rules) with external monitoring by the European Central Bank, Eurozone partners, and financial markets (notably bond rating agencies). Hence, the reforms did not put the Italian pension system on "autopilot" and put an end to ad hoc policymaking. Indeed one observer has characterized Italian pension policy over the last fifteen years as a process of "permanent reform” (Guardiancich 2010). 
Additional pieces of legislation, enacted in the last decade, have made both specific phased changes in the pension system and altered the structure of the NDC system. The first decennial change in the conversion coefficient never was adopted, and 2007 legislation shifted the timing of the adjustment to once every three years. Minimum retirement ages were raised in 2004, and ad hoc improvements to the pensions of the low-income elderly were made in 2002 and 2007 (Franco, Marino and Tommasino, 2008). In 2009 and 2010, Italy adopted a new stabilizing mechanism, again with a lag: an automatic increase in the standard retirement age linked to life expectancy. Under the 2010 law, enacted as part of a broader financial stabilization package, the first retirement age increase will take place in 2015, followed by 2019 and every three years thereafter, with a maximum increase in each step of 3 months.

In short, since adoption of the NDC system in 1995, Italian policymakers have employed several of the modification strategies discussed above for circumventing the automatic stabilizing mechanisms, including suspension of the planned 2005 conversion coefficient and some backtracking on seniority pensions. Overall, recent pension policy changes have strengthened stabilizing mechanisms rather than eroding them further. But this strengthening should not be attributed to the merits of the mechanism but to the deeply flawed nature of the original NDC reform and to Italy’s ongoing fiscal crisis.

\section{Automatic Stabilizers in the United States Social Security System}

The OASDI system already incorporates a substantial element of automatic adjustment to changes in economic trends. Both revenues and expenditures are adjusted for changes in price inflation. In addition, the real value of individuals' initial benefits are tied to their average earnings over their full work life, automatically adjusting benefit growth in line with rates of growth in taxable wages. However, higher rates of real wage growth do have a small positive impact on the system's finances. That is because higher wages increase taxable payroll immediately, but overall benefit levels rise only gradually as new beneficiaries become entitled. $^{13}$

\footnotetext{
${ }^{13}$ Price inflation does have a small positive impact on the system's finances, largely due to a 1-year lag in adjusting benefits. The positive impact of variations in real wages results from the decision to isolate the currently-retired from short-run variations in economic activity-relying on price rather than wage indexation.
} 
In contrast, the system incorporates no adjustment for changes in the underlying demographic trends. Thus, finances remain highly sensitive to changes in demographic trends. The large size of the baby-boom generation, for example, held down the costs of a pay-as-you-go system when they were working, but as they enter retirement, the costs to future cohorts of workers will surge. ${ }^{14}$ On balance, increases in prospective birth rates are good for the system's finances as the inflow of contributions precedes the outflow of benefits, but the Unites States is now entering the downside of that process. Increases in life expectancy add to benefit costs and worsen the financial balance.

The relative contribution of the demographic and economic determinants are highlighted in figure 2 by factoring the cost rate into its two components of a dependency rate (beneficiaries per covered worker) and the benefit rate (average benefit / average wage). It is evident that all of the projected increase in the cost rate can be traced to changes in demographic factors. Since the total fertility rate is projected to remain close to the average of the past two decades for the indefinite future, the sharp near-term increase in the dependency rate is a reflection of the size of the baby-boom generation, but it is also noteworthy that the rate remains high in the future, even after the baby boomers have died. That reflects the presumed continued increases in life expectancy.

Indexation of the retirement age to changes in life expectancy is a common proposal for adjusting to demographic change; and, as we discussed above, the adoption of a notional defined-contribution system in Sweden is another, more-extreme form of demographic indexation. We do not discuss the introduction of an NDC for the United States because of the complexity required to re-calibrate a system that previously embodied a large re-distributional component. ${ }^{15}$ Furthermore, the financing problems of the U.S. system are less severe than those that drove reforms in Sweden. Additional indexation of the parameters of the United States system is largely limited to future adjustments of the retirement age and a potential change in the measure of price inflation. We will discuss those and one other adjustment designed to prevent the continued erosion of the system's tax base. Beyond those three measures, we discuss the

\footnotetext{
${ }^{14}$ A similar influence originates from the rise in the female labor force participation rate, which added to the system's income in prior decades, but the effect on future benefit cost is muted by reduced reliance on spousal benefits.

${ }^{15}$ Most defined-contribution systems embodied a proportional relationship between life-time contributions and benefits. The redistribution component is split off into flat-benefit or means-tested programs.
} 
potential usefulness of a broader ASM aimed at directly stabilizing the system's basic financial balance.

\section{Life Expectancy and the Retirement Age}

The introduction of a mechanism for adjusting the retirement age for improvements in life expectancy is one of the most common suggestions for an ASM directed toward maintaining fiscal solvency. Without some adjustment, increases in longevity imply a steady increase in lifetime benefits and a growing gap between costs and revenues. Under a fixed retirement age, all of the increase in life expectancy is absorbed in increased retirement benefits. At the other extreme, the retirement age could be increased so as to keep the expected number of retirement years constant, assigning all of the increased life expectancy to the work life. A common intermediate alternative aims to stabilize the ratio of expected retirement to expected work life. For example, the United States maintained a retirement age for full retirement of 65 until 2000 when the retirement age was gradually increased to 66 for those born in 1943 to 1954 and then to 67 for those born in 1960 and later. Those changes have some of the features of ASMs in that they were introduced in the 1983 legislation with a long lead time and gradual phase-in, but they were not triggered with any automatic or formulaic link to life expectancy. If we used the early 1980s as a base of reference, the increase in the retirement age from 65 to 67, falls only modestly short of the goal of stabilizing the ratio of retirement to work life, and we would anticipate further increases to about 68 by 2030 and 69 in $2050 .{ }^{16}$

Within the OECD, about half of the member countries now report some recent linkage of public pensions to life expectancy, but this has been achieved in different ways. Several countries have made adjustments to their "standard" retirement ages on the basis of changes in life expectancy, but only a few explicitly index retirement ages to life expectancy. Some countries have adopted defined-contribution plans where the linkage is through the conversion of the pension balance to an annuity, implying an automatic reduction in the pension as life expectancy at retirement increases. Another option is the reliance of notional accounts, as in Sweden, where the benefit again reflects the principles of a defined-contribution system in terms of automatic adjustment for changes in life expectancy (OECD, 2011).

\footnotetext{
${ }^{16}$ Based on Bayo and Faber (1981), McMillen (1984) and estimates of life expectancy updated to the 2010 Trustees' Report.
} 
Adjusting the retirement age in response to changes in life expectancy raises two principal concerns. The first is the uncertainty as to whether reductions in mortality are associated with faster or slower rates of decline in morbidity, a delay in the onset of disabling disease. The evidence on this issue is quite mixed (Howse, 2006). The case for a reduction in the proportion of life in disability seems strongest for the United States, but that may be because life expectancy lags behind that of other high-income countries. In any case, the existence of a disability insurance (DI) program provides an escape mechanism for those who are not capable of continuing work.

The second issue arises out of the relationship between mortality and lifetime income. It has long been recognized that higher rates of mortality in the lower portions of the distribution of lifetime earnings offset a substantial portion of the progressivity imbedded in the social security benefit formula (CBO, 2006). The recent research has gone further to show that the differentials in mortality are growing over time (Cristia, 2007 and Waldron, 2007). Thus, while the old-age portion of Social Security is less progressive than it appears, it is also becoming less progressive over time. That research also suggests that increases in the retirement age would have much different effects on individuals at different positions in the distribution of lifetime earnings. ${ }^{17}$ Therefore, any change in the retirement age could be accompanied by changes to the basic benefit formula to restore some of the lost progressivity.

Several recent proposals, including that of the bipartisan National Commission on Fiscal Responsibility and Reform, have called for increasing the normal retirement age beyond 67 after 2022. A linkage to longevity improvements would suggest a rate of one month every two years. The estimated impact on the 75-year actuarial balance of the OASDI system would be about 0.4 percentage points in comparison to a current deficit of 2.2 percent of taxable payroll. ${ }^{18}$

\section{Cost-of-Living Adjustment}

Since 1975, Social Security benefits have been automatically adjusted on an annual basis for increases in the cost of living as measured by The Consumer Price Index for Urban Wage

\footnotetext{
${ }^{17}$ As with morbidity, this reduction in progressivity is ameliorated through the DI program.

${ }^{18}$ Office of the Chief Actuary of Social Security. Available at: http://www.ssa.gov/oact/solvency/provisions/summary.html
} 
Earners and Clerical Workers (CPI-W). ${ }^{19}$ The CPI is used to adjust for price inflation in a wide range of government programs, taxes and private-sector contracts. For example, it is the index used to define the return on Treasury Inflation Protected Securities (TIPS). Over the years, the method of computing the index has been periodically changed to better account for some of the technical problems with the prior methodology (See BLS Handbook of Methods, Chapter 17, pp 7-11for a historical summary).

In addition, the Bureau of Labor Statistics has published an experimental CPI that is designed to capture the effects of any substitution that consumers make across item categories in response to changes in relative prices. The published CPI, by ignoring those substitutions, overstates increases in the cost-of-living. Over the past ten years, the chained index has shown a rate of price index about 0.3 percent per year below the current index. The method has not been introduced within the regular CPI, however, because the expenditure data required to measure the substitution is available only with a significant time lag; the index is issued initially on a preliminary basis and is subject to revision after two-years. While the revisions would not be large and methods could be designed to forecast the revised values, the notion of a preliminary estimate is problematic for many of the current applications of the index, including TIPS and the computation of tax liabilities. Thus, there will be a continuing need to maintain the existing fixed-weight index.

Recent proposals for budget reform have suggested the use of the chained CPI for the annual cost-of-living adjustments to federal programs, including Social Security (National Commission on Fiscal Responsibility and Reform, 2010; and Bipartisan Policy Center, 2010). It is not evident how the proposals would deal with the issue of revisions in the index, but presumably they would be incorporated in the adjustment for a future year. If a chained version of the CPI should be adopted as the official index, there would be little controversy. Previous changes in the index have received widespread support, and the chained version is a similar step toward a more accurate measure of the cost of living. However, the introduction of a separate CPI to adjust government programs, while maintaining the existing official version is bound to

\footnotetext{
${ }^{19}$ The Bureau of Labor Statistics produces two measures of consumer price inflation: the CPI-U reflects the spending of a broader population of all urban consumers, whereas the CPI-W represents only about one-third of the population. However, the use of the CPI-W as the basis for the adjustment of benefits is mandated by law. In practice, the two indexes differ only in their expenditure weights, and there is little basis for anticipating a consistent pattern of difference in the estimated rates of price change (Bosworth (2011).
} 
generate considerable public controversy. The lack of a single CPI also weakens the argument that the changes are only directed toward producing a better measure of the change in the cost of living for an average American.

The adoption of a special CPI for government programs will also promote the advocacy of a special CPI targeted on the cost of living for the elderly. The creation of an experimental CPI that uses weights based on the consumption patterns of the elderly has been mandated by the Congress. While it is quite feasible to index the overall OASDI system to changes in the economy-wide rate of price inflation, the extension to a guarantee to the elderly for changes in their relative prices represents a significant and potentially costly extension of the basic program. Current studies indicate that a CPI for the elderly alone would rise more rapidly than the overall CPI-primarily because of the more rapid rate of increase in medical care prices. However, the accurate measurement of out-of-pocket costs for medical care is complex because payment and reimbursement rates for Medicare recipients are quite different from those for younger families covered by private insurance; nor is it clear that the two groups consume comparable combinations of medical care. In effect, the elderly would be reimbursed through OASDI for changes in the average cost of Medicare copayments, deductibles, and other uncovered payments. Any changes in Medicare payments would thereby be absorbed by the OASDI program, introducing an additional major source of uncertainty.

Notwithstanding the above concerns about revisions, the chained CPI does represent a significant conceptual improvement in the effort to produce a more accurate cost-of-living index. The impact of the change on the 75-year actuarial balance of OASDI is estimated at 0.5 percent of taxable payroll. ${ }^{20}$ Assuming that the new index is introduced in 2012, it leads to a rapid buildup in the overall effect on the cost rate; but because few persons live beyond 20 years of retirement, the savings are a stable portion of costs in the long run.

\section{Taxable Wage Base}

Social Security taxes are levied on covered earnings up to an earnings maximum. As part of the 1983 reforms, the Congress introduced automatic indexation of the taxable wage ceiling in line with increases in the economy-wide average wage index (AWI). At that time, taxable wages represented about 90 percent of all earnings of individuals covered by the program. However, because the earnings distribution has grown increasingly unequal over time a falling proportion

\footnotetext{
${ }^{20}$ http://www.ssa.gov/oact/solvency/provisions/summary.html
} 
of total wages are included under the wage ceiling, and the ratio of taxable to covered wages has fallen to 82-85 percent. The deterioration of the tax base has been a significant source of the worsening financial condition of the system. Many reform proposals, including the bipartisan commission have called for restoring the 90 percent ratio of taxable wages to covered wages. By stabilizing the ratio, revenues would rise by about one percent of taxable wages and there would be a delayed and smaller effect on benefits. If the adjustment were phased in over the next ten years, the long-run effect on the actuarial deficit is estimated at about 0.75 percent of taxable payroll.

The combined effect of the above three suggested reforms on the system's financial balance are illustrated in figure 3. The indexation of the retirement age essentially eliminates any further increase in the cost rate after the retirement of the baby boomers, and changing the measure of inflation would lower it by a further $1 / 2$ percent. In addition, stabilizing the share of taxable wages at the 1983 level would raise the income rate by about one percentage point during the phase-in period and then hold it constant in the future. Based on the intermediate projections, the net result is a reduction of the 75 -year actuarial deficit to about $1 / 2$ percent of taxable wages and the date of exhaustion of the trust fund would be extended out to 2060. However, the system would remain in deficit in the long run. The annual deficit would peak at about two percent of payroll in the 2030s, and then fall to about $1 \frac{1}{2}$ percent in the last half of the century.

\section{Financial Stability and Automatic Stabilizers}

A strong version of an ASM would be directed toward achieving financial balance of the overall system, rather than the simpler indexation of individual components to outside indicators. However, such a mechanism is not well-suited to the current U.S. situation. In the case of Canada and Sweden, where a financially-based ASM has been adopted, it was preceded by explicit legislative actions to create an initial reference of financial sustainability. The ASM was perceived more as an insurance policy against unforeseen changes in the economic or demographic determinants. In contrast, the United States begins with a substantial actuarial deficit, and the adoption of any ASM based on a forward-looking trigger will immediately initiate the need for policy change. Thus, it is equivalent to a decision to undertake current legislative actions to restore financial balance, albeit with some potential for phased adjustment. While both political parties fully understand the certainty of the looming crisis, there is a low probability that they could agree on a full set of remedial measures. 
The more likely-though undesirable- alternative is that the United States simply waits until the fund is exhausted. In terms of the earlier discussion of alternative forms of ASMs, the current legislation effectively embodies a certainty-based trigger, and it operates as a crisisresponding, rather than crisis-avoiding measure. The existing legislation prohibits borrowing and would require for an across-the-board reduction in benefits to the level of tax receipts-a balanced-budget requirement for Social Security. It is a poorly designed ASM in failing to give future retirees a clear signal of how the benefit reductions would be implemented, and its very severity virtually assures enormous political conflict when it is triggered. The current focus on the actuarial deficit over a 75-year horizon provides a triggering mechanism identical to that of Canada, but the political leadership has consistently refused to take action in the face of projected deficits extending back more than two decades.

The basic conclusion is that an ASM cannot substitute for explicit congressional action to resolve the financial problems of Social Security. Decisions need to be made about the distribution between revenue increases and benefit cuts and the composition of the measures on each side. Compared to the challenges faced by other countries, the financial problems seem quite manageable; the U.S. already has a very modest system and the long-run financial imbalance is small. However, the U.S. political system has also become more dysfunctional than most. The potential for an ASM seems limited to a post-reform measure directed at the risk of a future decline in the birth rate. It cannot be expected to play a significant role in the resolution of a preexisting deficit.

\section{Conclusion}

This paper has attempted to identify key design options for automatic stabilizing mechanisms in the United States and, using international evidence, to identify potential political challenges to sustaining ASMs once they are in place.

Several broad conclusions emerge from this study. A first conclusion is that ASMs should be viewed as one element of a broader package to promote the sustainability of Social Security, not as a panacea. More visible, and hence politically risky, changes will still be required. Phased changes that are specified by and enacted by statute-imposed with a lagshould also be a part of any package to restore the financial sustainability of the Social Security program, as they have been in most pension rescue packages in other OECD countries. One reason is that inclusion of an automatic balancing mechanism within a broader package that 
lowers its visibility is likely to make an ASM easier to adopt. An equally important reason for including phased statutory cutbacks — changes in the retirement age or replacement rates, for example- in a Social Security solvency package is that such cuts send clearer signals to workers about the need to change their savings and labor market exit behaviour than do possible future cutbacks under an automatic stabilizing mechanism.

A second conclusion, drawing on international evidence, is that automatic stabilizing mechanisms can take numerous forms in terms of their degree of automaticity and incidence of loss imposition. Perhaps most important, ASMs can be used both on the benefit side and the revenue side, both for the tax base and the tax rate (as in Canada). Indeed, a balanced sustainability package might include both an improvement in an existing stabilizing mechanism (shifting changes in the maximum taxable earnings base from changes in average earnings to changes in total earnings) as well as phased statutory changes that cut benefits and raise revenue.

Third, the country case studies clearly suggest that the sustainability of automatic stabilization mechanisms should not be taken for granted. As anticipated, ASMs are politically sustainable when they aren't used (Canada). But ASMs are prone to reversal or severe erosion after party change when they are enacted without opposition party support, as shown in the Kohl government’s “demographic factor” in Germany. More importantly, ASMs are vulnerable to modification over time, especially when the losses that the ASM would impose are substantial (notably during financial crises), and when elections are impending. The German and Swedish cases suggest that ad hoc interventions to mitigate potential benefit cuts can be a problem, especially during financial crisis and at the time of elections. Special procedures such as legislative supermajority requirements should in theory be useful in avoiding ad hoc interventions by politicians, but recent German and Swedish experience does not give much hope about the reality: once a proposal to ease ASM-imposed cuts is made by a large party, the incentives for other parties to climb on the bandwagon are strong.

Fourth, automatic balancing mechanisms are likely to be more sustainable if they too are phased in whenever the losses they will impose are substantial. The Canadian mechanism, which phases in any payroll tax increases over a three year period, and the revised Swedish automatic balancing mechanism, which smoothes the impact of fluctuations in buffer funds, are both examples of such mechanisms. In the case of Social Security, one possible mechanism would be to initially use solvency projection periods that are relatively short and lengthen them 
over time rather than requiring cuts to meet 75 year solvency projections all to be made in one year.

Finally, it is critical to recognize that many automatic stabilizing mechanisms transfer significant new risks to individuals, notably the risk of lower benefits due to demographic change and poor macroeconomic performance, and the risk of being unable to find appropriate (or any) work at an advanced age if workers are expected to stay employed longer to maintain a replacement rate similar to that enjoyed by current retirees (Scherman 2003). Any effort to impose pension cutbacks through automatic stabilizing mechanisms needs to take account of the implications of benefit cuts on low-income seniors. Across-the-board cuts in Social Security benefits of significant size would certainly push many American seniors into poverty. Several of the countries that use automatic stabilizing mechanisms (notably Sweden and Canada) have benefit floors that are substantially more generous than in the United States, and any Social Security reform changes could include means of moderating the effects for low-income retirees even if it means a flattening of benefits.

Overall, the analysis in this paper suggests that automatic stabilizing mechanisms are no panacea for the problems of countries facing serious long-term pension financing problems. ASMs are perceived as devices to get politics out of pension politics, but they are inevitably devices that are creations of, vehicles for, and potentially victims of, politics. At each stage of the policymaking process for ASMs — design, enactment, implementation, and sustaining - they require a combination of substantive expertise with willingness on the part of multiple political actors to expend scarce political capital and cooperate with present and likely future adversaries rather than generating blame against those adversaries. Moreover, they require effective political strategizing in doing so. These are tough requirements, even under favorable institutional arrangements and political conditions. 


\section{References}

Aaron, Henry J. 2011. “Social Security Reconsidered,” National Tax Journal, Vol. 64. No 2, Part 2, 385-414.

Anderson, Karen M., and Ellen M. Immergut. 2007. “Sweden: After Social Democratic Hegemony,” pp. 349-395 in Ellen M. Immergut, Karen M. Anderson and Isabelle Schulze, The Handbook of West European Pension Politics, Oxford and New York: Oxford University Press, 349-395.

Anderson, Karen M., and Julia Lynch. 2006. "Reconsidering Seniority Bias: Aging, Internal Institutions, and Union Support for PensionReform,” Comparative Politics, Vol. 39, No. 2, 189-208.

Anderson, Karen M., and Traute Meyer. 2003. "Social Democracy, Unions, and Pension Politics in Germany and Sweden,” Journal of Public Policy, Vol. 23, No. 1, 23-54.

Bayo, Francisco R., and Joseph F. Faber. 1981. “Equivalent Retirement Ages: 1940-2050,” Actuarial Note Number 105, Office of the Actuary, Social Security Administration.

Board of Trustees, Federal Old-Age and Survivors Insurance and Disability Trust Funds (2011). Annual Report. Washington: U.S. Government Printing Office.

Brandstetter, Barbara. 2009. "So wird unsere Rente aufs Spiel gesetzt”, Welt am Sonntag, Available at: http://www.welt.de/die-welt/finanzen/article5218526/So-wird-unsere-Renteaufs-Spiel-gesetzt.html (November 15).

Bundesministerium fuer Arbeit und Soziales. 2009. 'Renten steigen um 2,41 bzw. 3,38 Prozent gerechte Teilhabe am hart erarbeiteten Wohlstand', Available at:

http://www.bmas.de/portal/31766/2009_03_16_renten_steigen.html (March, 16, 2009).

Busemeyer, Marius R.. 2005. "Pension Reform in Germany and Austria: System Change vs. Quantitative Retrenchment,” West European Politics, Vol. 28, No. 3, 569-591.

Chłoń-Domińczak, Agnieszka, Daniele Franco, and Edward Palmer. 2009. "The First Wave of NDC - Taking Stock Ten Years Plus Down the Road,” Stockholm: Försäkringskassan, 2009.

Der Spiegel. 2009. 'Renten steigen deutlich an', Available at: http://www.spiegel.de/wirtschaft/0,1518,613598,00.html (March, 16, 2009).

Deutsche Bundesbank. 2008. "Outlook for Germany’s Statutory pension Insurance Scheme," Monthly Report, Vol. 60, No. 4, 47-72.

Eggertson, Laura. 1998. "Firing of CPP Watchdog to Be Probed," Toronto Star, September 23.

Federal/Provincial/Territorial CPP Consultations Secretariat. 1996. “An Information Paper for Consultations on the Canada Pension Plan,” Ottawa: Department of Finance, February.

Ferguson, Derek. 1997. "73\% Premium Increases to Save Pensions: Martin," Toronto Star, September 26.

Ferrera, Maurizio and Matteo Jessoula. 2005. "Reconfiguring Italian Pensions: From Policy Stalemate to Comprehensive Reforms,” in Giuliano Bonoli and Toshimatsu Shinkawa, 
eds., Ageing and Pension Reform Around the World: Evidence from Eleven Countries, Cheltenham: Edward Elgar, 24-46.

Focus. 2008. 'Renten steigen dank Formel-Trickserei', Available at:

http://www.focus.de/finanzen/altersvorsorge/altersbezuege_aid_265158.html (March, 14, 2008).

Försäkringskassan. 2009. Orange Report: Annual Report of the Swedish Pension System 2008.

Franco, Daniele, and Nicola Sartor. 2006. "NDCs in Italy: Unsatisfactory Present, Uncertain Future," in Robert Holzmann and Edward Palmer, Pension Reform: Issues and Prospects for Non-Financial Defined Contribution (NDC) Schemes, Washington, D.C.: The World Bank, 467-492.

Galak, Oliver. 2007. “Un hombre de Moreno asume una dirección clave en el Indec” [“A Moreno Man Assumes a Key Leadership Role in Indec”], La Nación [Buenos Aires], July 14.

Goss, Stephen C. 2010a. "Estimates of the OASDI Financial Effects of Restoring America's Future - a plan developed by the Bipartisan Policy Center's Debt Reduction Task Force.” Social Security Administration. http://www.ssa.gov/oact/solvency/

Goss, Stephen C. 2010b. "Estimates of the OASDI Financial Effects of the plan developed by National Commission on Fiscal Responsibility and Reform.” Social Security Administration. http://www.ssa.gov/oact/solvency/

Guardiancich, Igor. 2010. Italy-Current Pension System: First Assessment of Reform Outcomes and Output, Brussels: European Social Observatory.

Hering, Martin. 2008. "Welfare State Restructuring without Grand Coalitions: The Role of Informal Cooperation in Blame Avoidance,” German Politics, Vol. 17, No. 2, 165-183.

Hinrichs, Karl. 2005. "New Century - New Paradigm: Pension Reforms in Germany.” In Giuliano Bonoli and Toshimitsu Shinkawa., eds., Ageing and Pension Reform Around the World, Cheltenham, UK: Edward Elgar Publishing, 47-63.

Jack, Ian. 1998a. "Don't Embarrass Martin: Fired Actuary Says Boss Twice Asked Him to Alter CPP Numbers," National Post, October 1, 3.

Jack, Ian. 1998b. "Actuary Was Asked to Look at 'Alternative' CPP Analysis," National Post, December 3.

Jack, Ian. 1999. "Federal Auditor Plans to Keep Sharp Eye on CPP," National Post, January 8, p. C3.

Jacobs, Alan M.. 2009. "How Do Ideas Mater: Mental Models and Attention in German Pension Politics,” Comparative Political Studies, Vol. 42, No. 2, 252-279.

Krieger, T. \& Stoewhase, S.. 2009. 'Diskretionaere rentenpolitische Maßnahmen und die Entwicklung des Rentenwerts in Deutschland von 2003-2008', Zeitschrift fuer Wirtschaftspolitik, Vol.1, 36-54.

Hans-Jürgen Krupp. 1999. “Grenzen von Rentenanpassungsformeln,” Wirtschaftsdienst 1999, 474-479.

Kruse, Agneta. 2009. "Rör inte min pension! Om värdet av stabila spelregler även i nedgång,” Ekonomisk Debatt, No. 7, 6-10. 
Nexis. 2008. 'Gesetz zur Rentenanpassung 2008 im Bundestag verabschiedet', LexisNexis, Available at: http://www.lexisnexis.de/rechtsnews/gesetz-zur-rentenanpassung-2008-imbundestag-verabschiedet-138023 (May, 9, 2008).

Little, Bruce. 2008. Fixing the Future: How Canada's Usually Fractious Governments Worked Together to Rescue the Canada Pension Plan, Toronto: University of Toronto Press.

McMillan, Marilyn. 1984. “Sex-Specific Equivalent Retirement Ages: 1940-2050,” Social Security Bulletin, Vol. 47, No. 3.

Office of the Superintendent of Financial Institutions, Chief Actuary. 1997. Canada Pension Plan Sixteenth Actuarial Report, September 1997, Ottawa: Office of the Superintendent of Financial Institutions, September 24.

OECD. 2009., Pensions at a Glance 2009: Retirement-Income Systems in OECD Countries (latest edition available at www.oecd.org/els/social/pensions/PAG).

OECD. 2011. Pensions at a Glance 2011: Retirement-Income Systems in OECD and G20 Countries (www.oecd.org/els/social/pensions/PAG).

Palmer, Edward. 2002. "Swedish Pension Reform: How Did It Evolve, And What Does It Mean for the Future?,” pp. 171-205 in Martin Feldstein and Horst Siebert, eds., Social Security Pension Reform in Europe, Chicago and London: University of Chicago Press.

Patashnik, Eric M. 2003. "After the Public Interest Prevails: The Political Sustainability of Policy Reform,” Governance, (April), 203-234.

Patashnik, Eric M. 2008. Reforms at Risk: What Happens After Major Policy Changes Are Enacted, Princeton: Princeton University Press.

Prince, Michael J. 2003. "Taking Stock: Governance Practices and Portfolio Performance of the Canada Pension Plan Investment Board,” pp. 134-154 in G. Bruce Doern, ed., How Ottawa Spends 2003-2004: Regime Change and Policy Shift, Toronto: Oxford University Press.

Schulze, Isabelle, and Sven Jochem. 2007. “Germany: Beyond Policy Gridlock,” in Ellen M. Immergut, Karen M. Anderson and Isabelle Schulze, The Handbook of West European Pension Politics, Oxford and New York: Oxford University Press, 660-710.

Schludi, Martin. 2005. The Reform of Bismarckian Pension Systems: A Comparison of Pension Politics in Austria, France, Germany, Italy and Sweden, Amsterdam: Amsterdam University Press.

Settergren, Ole. 2001. The Automatic Balancing Mechanism of the Swedish Pension System: A Non-Technical Introduction, National Social Insurance Board, Working papers in Social Insurance 2001:2.

Settergren, Ole. 2003. “The Reform of the Swedish Pension System-Initial Results,” Revue Française des Affaires Sociales, 2003, 4, 369-391.

Settergren, Ole. 2010. "Impact of the Financial and Economic Crisis on the Swedish Pension System,” Social Security Observer, no.10 (September),

http://news.issa.int/eng/newsletter/newsletter_repository/observer/en/social_security_obser ver_10/(article)/4547 accessed December 22, 2010.

Slater, David W. and William B.P. Robson. 1999. Building A Stronger Pillar: The Changing Shape of the Canada Pension Plan, Toronto: C.D. Howe Institute, March. 
Sueddeutsche Zeitung. 2008. 'Kabinett beschließt Rentenerhöhung', Sueddeutsche Zeitung, Available at: http://www.sueddeutsche.de/politik/altersvorsorge-kabinett-beschliesstrentenerhoehung-1.219562 (April, 8, 2008).

Sweden, Ministry of Health and Social Affairs. 2002. National Strategy Report on the Future of Pension Systems.

Turner, John A. 2007. "Promoting Work: Implications of Raising Social Security’s Early Retirement Age.” Work Opportunities Brief 12. Chestnut Hill, MA: Center for Retirement Research at Boston College.

Turner, John. 2009. Social Security Financing: Automatic Adjustments to Restore Solvency, AARP Research Report \#2009-01, February 2009.

Weaver, R. Kent. 1988. Automatic Government: The Politics of Indexation, Washington, D.C.: The Brookings Institution.

Åsbrink, Erik. 2008. "Höjt utgiftstak krävs för att rädda pensionema" [’Extended ceilings needed to save pensions”], Dagens Nyheter, November 18, 2008. 
Figure 1. Social Security Costs and Income, 1970-2086.

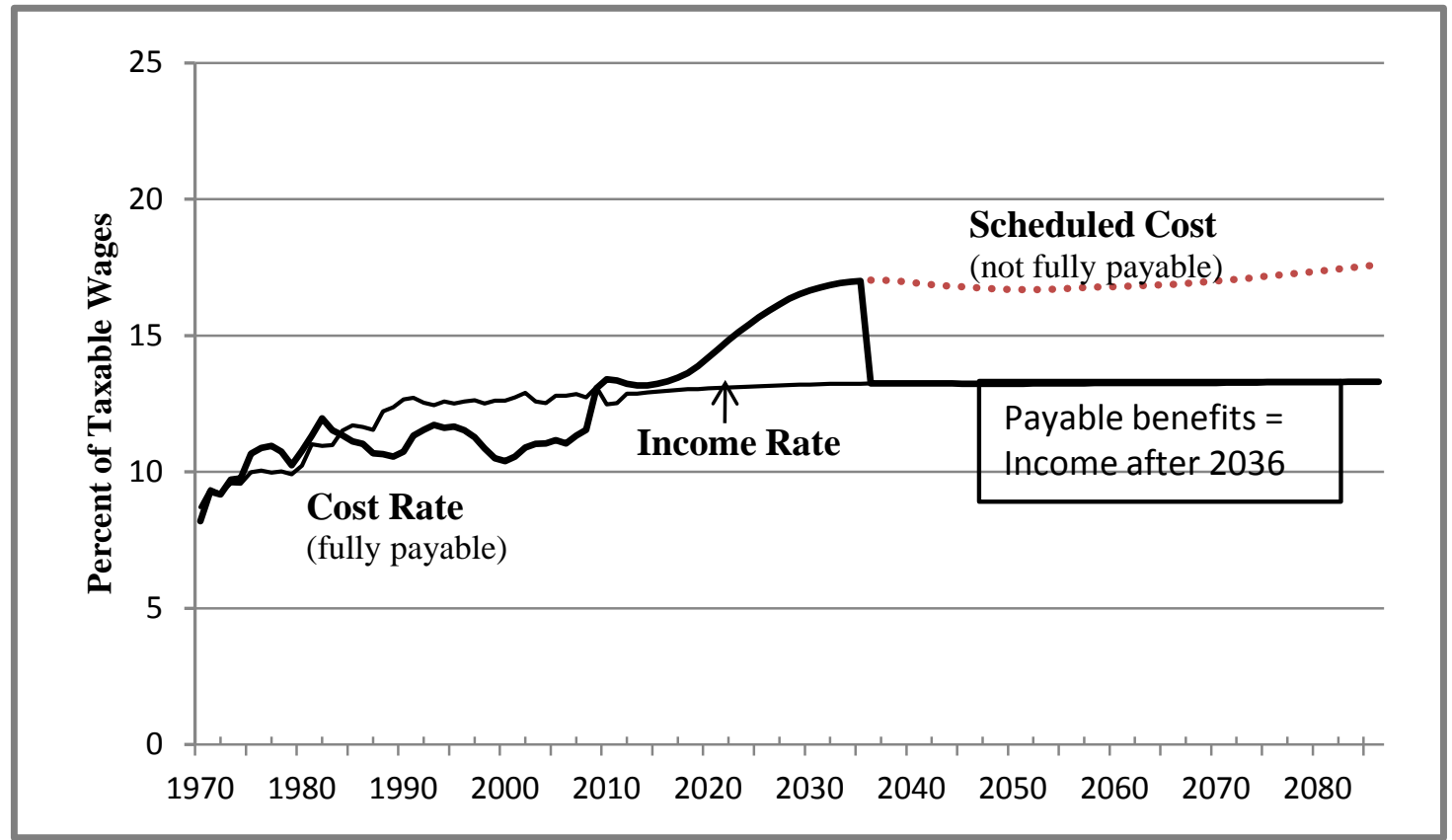

Source: Social Security Administration website, May 2011.

Figure 2. Demographic and Economic Determinants of the Cost Rate, 1970-2085.

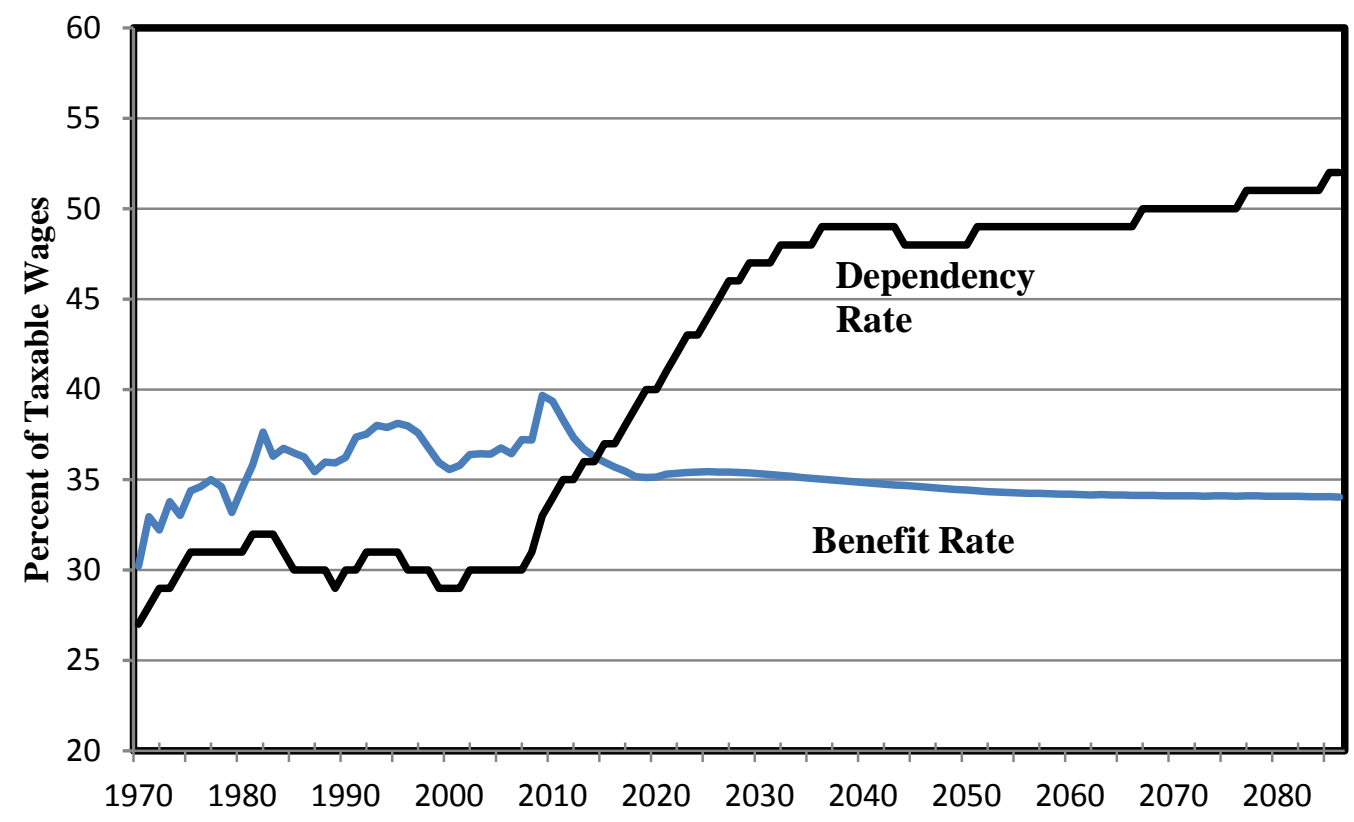

Source: Social Security Administration website, May 2011. 
Figure 3. Effects of Three Reforms on Financial Condition of the OASDI Fund, 2010-2085 Percent of taxable wages

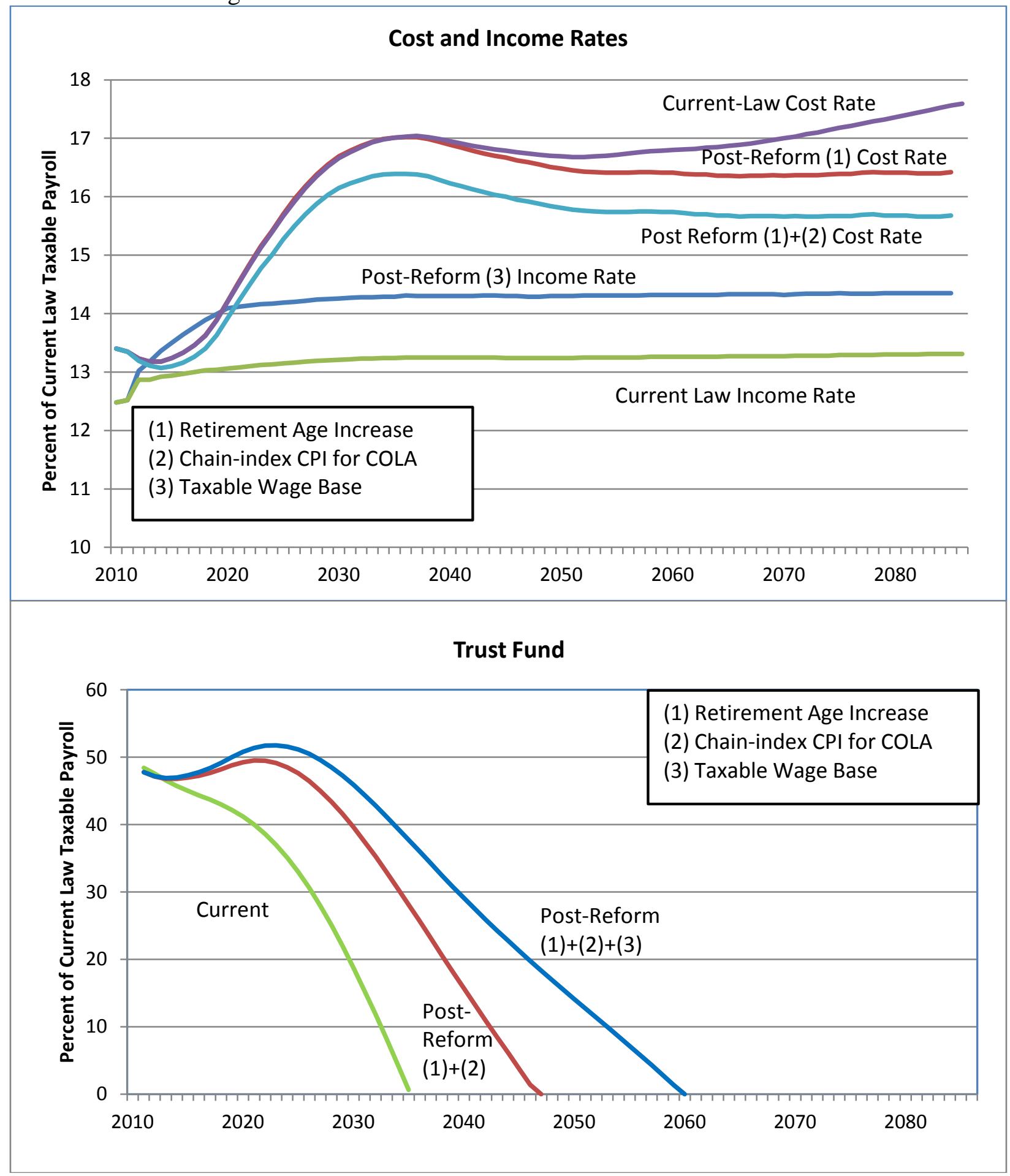

Source: Social Security Administration, Office of the Actuary, Trustees' Report (2011), and authors' calculations. 
Table 1. Pension Benefits in Selected Countries by

Earnings, 2011

\begin{tabular}{lccc}
\hline & \multicolumn{3}{c}{ Individual earnings, multiple of mean } \\
\cline { 2 - 4 } Gross Pension & 0.5 & 1 & 1.5 \\
Canada & 13.7 & 8.0 & 5.3 \\
France & 11.4 & 10.0 & 8.4 \\
Germany & 8.5 & 8.5 & 8.5 \\
Italy & 10.9 & 10.9 & 10.9 \\
Japan & 8.9 & 6.4 & 5.6 \\
Sweden & 12.2 & 9.7 & 12.2 \\
UK & 8.3 & 4.9 & 3.5 \\
US & 8.3 & 6.3 & 5.6 \\
OECD34 & 13.2 & 10.4 & 9.4 \\
& & & \\
Gross Replacement Rate, percent of individual gross & \\
earnings & & & \\
Canada & 76.6 & 44.4 & 29.6 \\
France & 55.9 & 49.1 & 41.3 \\
Germany & 42.0 & 42.0 & 42.0 \\
Italy & 64.5 & 64.5 & 64.5 \\
Japan & 47.9 & 34.5 & 30.0 \\
Sweden & 68.3 & 53.8 & 68.7 \\
UK & 53.8 & 31.9 & 22.6 \\
US & 51.7 & 39.4 & 35.3 \\
OECD30 & 72.1 & 57.3 &
\end{tabular}

Source: OECD, 2011.

1. Gross pension wealth was averaged for men and women.

2. Gross replacement rate is for men only. 


\section{RECENT WORKING PAPERS FROM THE CENTER FOR RETIREMENT RESEARCH AT BOSTON COLLEGE}

The Impact of Unemployment Insurance Extensions on Disability Insurance Application and Allowance Rates

Matthew S. Rutledge, October 2011

Do Couples Self-Insure? The Effect of Informal Care on a Couple's Labor Supply

Norma B. Coe, Meghan Skira, and Courtney Harold Van Houtven, October 2011

How Prepared are State and Local Workers for Retirement?

Alicia H. Munnell, Jean-Pierre Aubry, Josh Hurwitz, and Laura Quinby, October 2011

Social Security Reform and Male Labor Force Participation Around the World Jocelyn E. Finlay and Günther Fink, September 2011

Corporate Pension Plan Investments in Alternative Assets: Determinants and Consequences

Divya Anantharaman, August 2011

Social Security Reform and Male Labor Force Participation Around the World Jocelyn E. Finlay and Günther Fink, June 2011

An In-Depth Look into Intergenerational Flows

Oksana Leukhina and Marika Santoro, May 2011

Who Retires Early?

Henry J. Aaron and Jean Marie Callan, May 2011

The Potential Impact of the Great Recession on Future Retirement Incomes Barbara A. Butrica, Richard W. Johnson, and Karen E. Smith, May 2011

Immigrant Diversity and Social Security: Recent patterns and Future Prospects Melissa M. Favreault and Austin Nichols, May 2011

Why Aren't More Families Buying Life Insurance?

Matthew S. Chambers, Don E. Schlagenhauf, and Eric R. Young, March 2011

Changes in Firm Pension Policy: Trends Away From Traditional Defined Benefit Plans Kandice A. Kapinos, February 2011

Interdependent Durations in Joint Retirement

Bo Honoré and Áureo de Paula, February 2011

All working papers are available on the Center for Retirement Research website (http://crr.bc.edu) and can be requested by e-mail (crr@bc.edu) or phone (617-552-1762). 